\title{
18 Regulating corporations in global value chains to realise labour rights for homeworkers
}

\author{
Marlese von Broembsen
}

\section{Introduction}

Labour law distinguishes employees from what it terms independent contractors. Labour law protects employees, whereas law of contract notionally protects independent contractors. In most jurisdictions, homeworkers are considered to be independent contractors.

The premise of the law of contract is that the parties to a contract should be free to contract on whatever terms they wish, even if to their detriment. Courts should honour the "will of the parties" and not interfere in the terms of the contract, unless there are strong public policy imperatives, such as illegal activities. ${ }^{1}$

Unless required by legislation, contracts need not be in writing. A valid contract simply requires a "meeting of minds" and agreement on material terms, such as what is being exchanged, for how much, and the delivery date. Imagine the following agreement between a homeworker and an intermediary:

1 The contractor (who might be an employee, an independent contractor, or an agent of the factory) - will deliver pre-cut fabric to the homeworker and collect completed T-shirts at an agreed time.

2 The homeworker will provide the sewing machine, the thread, electricity and the work space.

3 The homeworker will be paid $\mathrm{X}$ per piece.

4 Poor quality goods will be rejected by the contractor's unilateral decision.

5 The contractor will pay on receipt of goods.

Were the bargaining power distributed equally between the parties, we would likely agree that the terms are fair. The problem is that the terms are not negotiated, but imposed by the contractor on a take-it-or-leave it basis; the piece-rate is almost always below the equivalent minimum wage for the sector (Pieper and Putri 2017; Zhou 2017) and does not cover the homeworker's production costs, excludes social protection costs (such as health care or sick leave); the relationship between the contractor and homeworker is seldom arm's-length: the contractor may be from the same community and might also be the (male) money-lender, or (male) kin, which affects their power relations; and the contract is embedded 
within a particular mode of production, known as value chains, which fundamentally impacts on the contractual terms. ${ }^{2}$

This last point needs elaboration. The contemporary form of transnational production is attributable to technological innovation, lower transport costs, exchange control de-regulation, the World Trade Organisation law that has reduced import tariffs, low wages in developing counties, but also to a development ideology that includes "labour flexibility" as a goal for governments and corporations (Collins 1990; Baldwin 2011). ${ }^{3}$ Standing (1999) argues that labour flexibility comprises four aspects. (1) production or organisational flexibility refers to corporations' practice of keeping the profitable functions (such as research and development, branding and marketing) and outsourcing or subcontracting less profitable aspects, such as production that can be commoditised (Klein 1999); (2) wage system flexibility targets the wage costs of production: firms reduce their wage costs by restructuring their relationships with workers to avoid the responsibilities that come with an employment contract, including by sub-contracting work; (3) labour cost flexibility targets the non-wage component of labour, including social protection (such as unemployment insurance), compensation for injuries at work, sick leave and supervision costs. Firms find ways to transfer these costs to other firms and/or to their workers and these firms (factories) in turn transfer these costs to sub-contracted labour, including homeworkers; and, finally, (4) numerical flexibility means firms hire when market demand is high and lay off when demand is low. Typically, they hire casual, part-time or sub-contracted labour (including homeworkers) for high demand periods, which enables them to transfer the costs and risks of fluctuating demand to these workers. Hiring homeworkers enables manufacturing companies to achieve all four forms of labour flexibility.

A recent global survey (ILO 2017) of 1,454 suppliers to multinational enterprises (MNEs) from 87 countries by the International Labour Organization shows that MNEs continually pressurise suppliers to drop their prices. Up to 52 per cent of suppliers that were surveyed sign contracts to produce goods at a loss. The primary reason they do so, is to secure future orders. Demanding unpaid overtime and keeping wages low for regular workers, combined with outsourcing to homeworkers who are paid even less and enjoy fewer labour rights, are the suppliers' primary tactics for keeping costs low.

In this environment, what might the best legal strategy be to secure labour rights for homeworkers, including the right to freedom of association and collective bargaining? Would it be to expand the concept of "employee" in which to reclassify homeworkers as several jurisdictions have done? Or devise a separate category called "dependent" contractors" in which to classify homeworkers, as the 20th International Conference of Labour Statisticians has recommended? ${ }^{4}$ Should we look to contract law and regulate contracts between contractors and homeworkers? Should we look to human rights law, as per the International Trade Union Confederation (ITUC) approach in crafting international law instruments? Which approaches would work across jurisdictions to address the problem of mobile capital? And which approaches hold most possibility to 
address the unfettered power of brands and retailers that enables them to conclude contracts with suppliers that allow them to pay $\$ 4$ per T-shirt - a dollar less than the $\$ 5$ they paid 20 years ago (Baldwin 2011) and to coerce suppliers to agree to produce goods at a loss?

This chapter discusses two international human rights law initiatives and three different approaches adopted by countries; and offers brief comments on an analytical framework as we craft legal strategies for protecting homeworkers.

\section{International law}

The ITUC adopted a human rights approach in its negotiations for international legal instruments. Both the revised ILO MNE Declaration (which is likely to become a Convention), and the Due Diligence Guidance for Responsible Supply Chains in the Garment and Footwear Sector (the "Guidance") 5 incorporate the UN Guiding Principles on Business and Human Rights.

According to the Guiding Principles, businesses should assume responsibility for addressing "human rights impacts" attributable to their commercial activities, and prevent or mitigate behaviour by other actors in their supply chains (such as suppliers or sub-contractors) that violate workers' human rights (Ruggie 2011). Businesses must draft a policy commitment to human rights, which should be distributed to all their stakeholders, and undertake a due diligence of their supply chains to assess whether the production processes might violate workers' rights. These rights are found in the Universal Declaration of Human Rights, ${ }^{6}$ the ILO Declaration on Fundamental Principles and Rights at Work, and national legislation. According to the Guiding Principles, businesses should use their "leverage" with suppliers to incorporate labour/ human rights in their procurement contracts and to terminate relations with recalcitrant suppliers. They should act if workers' rights might potentially be violated, and should implement a remediation process if workers have suffered human rights violations.

The OECD's (2017) Due Diligence Guidance for Responsible Supply Chains in the Garment and Footwear Sector (the "Guidance") includes a section on homeworkers, which recommends particular practices. Businesses are encouraged to identify production processes and countries where homeworkers are likely to be prevalent and to assess whether their suppliers' procedures for sourcing from homeworkers are responsible. The recommendations also encourage businesses to engage governments to promote homeworkers' rights and to promote their equal treatment to other workers (OECD 2011). The Guidance is addressed to multinational enterprises (MNEs) and includes their subsidiaries. Importantly, it applies to all sectors and sizes, including small and medium-sized enterprises. The criteria for the Guidance to be applicable is that the business must either operate or be based in a country that is a signatory to the Guidelines. This means that domestic companies also have to adhere to the Guidelines if they are based in a country that adheres to the Guidelines. The list of adhering countries includes the 36 OECD countries, and 12 non-OECD countries. 
Human rights discourse can, and does, shift public consciousness, which in itself is a form of regulation: market actors change their behaviour in the face of sanctions such as potential consumer boycotts. However, compliance by businesses with the instruments is voluntary, and the focus is on businesses securing their suppliers' compliance and not on challenging their own procurement practices. In the case of the OECD Guidance, homeworkers could take a case to the national contact point (NCP) in the country in which the MNE is domiciled and the NCP could make a non-binding finding against the MNE. Even if an MNE is not bound by the decision, such a strategy renders homeworkers more visible, and enables them to shape the public discourse about homework.

\section{National legislation}

National legislation employs one of three approaches. The most common approach expands the traditional employment/labour relations legislation that covers employees to include sub-contracted work, including homeworkers, which effectively extends labour rights to homeworkers on the basis that they are disguised employees. The second approach, pioneered by Thailand, is to legislate that the contract between "hirers" and homeworkers must satisfy certain conditions for the contract to be valid and legal. The third approach is to combine a "due diligence" human rights approach with a "mandatory code" that regulates the terms of contract. The chapter briefly discusses each, and their method of enforcement.

Countries such as Bulgaria, Chile, Morocco, Nicaragua, South Africa and Tanzania have amended their existing labour legislation to include subcontracted work ("disguised employment"). The weakness of this approach is two-fold: first, if the homeworker is contracted directly by a factory, the legislation would help her show that she is de jure the factory's employee and that she is entitled to the same rights as other employees. If, however, she is contracted through an intermediary contractor, including another homeworker, she may only be able to establish an employment relationship with the intermediary, and not with the factory (unless the intermediary is a factory employee or unless an agency relationship can be proved). The claims for labour rights are therefore against an intermediary contractor who might have as little bargaining power as the homeworker. The Thai legislation has the same effect, in that the "hirer" is liable and the legislation does not address the hirer's claim against the factory. Second, if a homeworker works for three different intermediaries, she may not be able to satisfy a court that any one is her employer. Australia's legislation, by contrast, regulates the entire chain, rather than the "employment" relationship only. ${ }^{7}$ The homeworker can claim from anyone who she regards as the "employer" and if that person is an intermediary contractor, he can make a claim against the actual employer.

The three approaches differ in another important respect. For the first two approaches, the burden of enforcement rests with homeworkers. ${ }^{8}$ In Australia, by contrast, several chain actors bear responsibility for enforcement. The retailers, 
factories, suppliers and contractors each have transparency and disclosure duties to the state, and to the trade union. They have a duty if they sell their products in the particular state if they have procured from homeworkers in any state of Australia, even if that state does not have the same legislation. The state has a duty to inspect and can be a party to litigation, and trade unions participate in enforcement by reviewing the details reported by the retailers and other parties, and have powers of inspection. This approach reflects "new governance" (Lobel 2007) theories of regulation, according to which the responsibility of enforcement is distributed across several actors, including self-regulation by the private sector, and by civil society (such as unions and non-governmental organisations, NGOs) and incentives and enforcement mechanisms (such as duties of transparency, benchmarks, best practice goals, etc.) are deployed. In the Australian example, the combination of hard (state) and soft (new governance) regulatory mechanisms has proven to be particularly effective. ${ }^{9}$

\section{Looking ahead}

Even if national law is effective, capital can, and does, move to countries with less onerous regulation or weaker enforcement (Pieper and Putri 2017). A pluraloverlapping conception of governance is therefore critical, meaning that many different forms of governance at different jurisdictional spheres should co-exist. Governance is needed at the global, regional, national and state level, and no one-size-fits-all: different models of regulation and enforcement are feasible and effective in different political, cultural and institutional contexts. ${ }^{10}$ For example, the Australian legislation was possible because of strong union pressure and union capacity to enforce the legislation (Rawlings 2014).

The menu of enforcement options needs to be expanded beyond reliance on homeworkers to go to court or to a labour tribunal, since the evidence suggests that they would rather be exploited than complain and risk losing their work (Sinha and Mehrotra 2016; von Broembsen 2018). New governance theory offers options that might be used creatively for homeworker organisations to participate in enforcement.

The UK Modern Slavery Act and the Californian Transparency in Supply Chains Act, which address forced labour, ${ }^{11}$ are weak in terms of the responsibilities of businesses or the sanctions against them for non-compliance, but from a legal perspective, the innovation of these two national Acts lies in regulating not only their domestic corporations' dealings in other countries, but also foreign corporations that sell products to their consumers. They demonstrate that, with sufficient political will, governments of developed countries can regulate the activities of both multinationals incorporated in their territories that do business in other countries, and multinationals that are not incorporated in their jurisdiction, but sell to their domestic markets. These legal strategies could therefore be extended to incorporate other rights violations.

Homeworker organisations could use international law mechanisms - ILO mechanisms for countries that have ratified Convention 177, and national contact 
points (NCPs) in countries that have effective NCPs and are the home country of multinational corporations with homeworkers in their supply chains. Consider Bulgaria, which has ratified ILO Home Work Convention 177 (C177), concluded a national agreement with trade union federations and with TUSIV "Edinstvo" (UNITY in English), the Bulgarian trade union of informal workers. The government subsequently amended its Labour Code so that homeworkers are treated on equal terms with other employees, in accordance with C177. But the Ministry of Labour and Social Policy has failed to enforce the amended legislation, claiming that in the absence of written contracts, homeworkers are not entitled to the Labour Code's Chapter VIII provisions for homeworkers.

A country is required to report to the ILO two years after ratifying a Convention on its progress on implementation, and thereafter every five years. The most representative trade union federation and employer organisation may comment on their government's report; they may also submit their own independent reports on the implementation, both in law and in practice, of the convention concerned. In 2014, UNITY sent a letter to the ILO Committee of Experts on the Application of Conventions and Recommendations (CEACR). The CEACR asked the government to respond to these charges in its next report and asked for research on homeworkers' terms and conditions of work. Bulgaria's next report was due by 1 September 2018. In August 2018, UNITY submitted its own report to the CEACR, and the CEACR has asked the trade union federation and the government to respond. Whereas the most representative trade union originally agreed with the government's position, its final report quoted sections of UNITY's report. Also UNITY asked researchers from WIEGO to write a research report on homeworkers' terms and conditions of work, which it also submitted to CEACR.

The CEACR used UNITY's report and WIEGO's research as the basis of its comments and questions to the Bulgarian government. CITUB, the trade union federation, initially supported the government position, namely, that homeworkers are independent contractors unless they have employment contracts. Once the CEACR asked CITUB to respond to UNITY's report, CITUB changed its position to support UNITY's argument that the legislation does not reflect the national agreement that was signed in November 2018.

The CEACR's final comments to the Bulgarian government are the following:

The Committee requests the Government to provide detailed information on specific steps taken or envisaged to ensure equality of treatment between homeworkers and other workers, including by consulting the social partners concerned with a view to identifying homeworkers in an employment relationship, within the meaning of Article 1 of the Convention, who should be benefiting from the protections afforded by the Labour Code. Further recalling that paragraph 13 of the Home Work Recommendation, 1996 (No. 184), provides that minimum rates of wage should be fixed for home work in accordance with national law and practice, the Committee asks the Government to reply in detail to the observations raised by UNITY in relation to the low level of wages earned by home workers. 
The Committee requests the Government to provide detailed information concerning the measures adopted or envisaged to improve the situation of homeworkers, and to identify the employers' and workers' organisations that have been consulted with regard to the development, implementation and review of such measures. ${ }^{12}$

The CEACR's "requests" addressed to the government are merely requests which the government may or may not address in its report in five years' time. The ILO reporting mechanism is therefore very weak as a mechanism to enforce compliance with ratified conventions. But the story illustrates the fact that if a representative organisation of homeworkers has voice in an international forum, it can shift the power relations and the discourse on homework within a country. Since the CEACR's request, the government has been willing to engage with UNITY again. It is paying for a meeting on homework, which UNITY is organising, and to which UNITY may invite its members as well as international speakers and the ILO's international standards department.

Finally, transnational HomeNets should engage with global sector unions for homeworkers to be recognised and protected in global framework agreements with brands, and in the provisions in trade agreements that aim to protect labour rights.

\section{Notes}

1 Unlike common law countries, many civil law (non-Anglo-Saxon) countries' law of contract requires parties to observe a duty of good faith.

2 Terms used by different disciplines include global supply chains; global value chains; global production networks and global commodity chains. See Sturgeon (2009) for a nuanced discussion of the different disciplines and literatures that contribute to global value chain analysis, including economic geography, economic sociology, strategic management and transaction costs economics.

3 See Baldwin (2011), who distinguishes between a first and second "unbundling" of production and who argues that while global value chains are not new, this second, contemporary "unbundling" has different characteristics to the first. For example, in the first unbundling, MNEs would establish a plant in a country through a subsidiary, i.e., production was vertically integrated, in that the MNE owned shares in its suppliers. With the second unbundling, MNEs have do not own shares in their suppliers, who are legally autonomous firms.

4 WIEGO colleagues were members of the Expert Group on the Revision of the International Classification of Status in Employment that worked on proposed criteria for such a category in international statistics, but no such category yet exists in law, as far as I am aware, despite debates since the 1960s. See Harry Arthurs (1965-66).

5 Since the 2011 update to the Guidelines, the OECD has clarified what the due diligence process should involve and a due diligence guidance has been developed for five different sectors including the garment and footwear sector - a key sector for homeworkers.

6 See Sections 23-5, which pertain to all workers, including homeworkers.

7 Brazil has also adopted a supply chain approach. The National Labour Law, which was promulgated in 1943, states that companies that outsource production share the responsibility for the rights of workers in their supply chain (Tilly et al. 2013). The 


\section{Marlese von Broembsen}

textile sector union has used this legislation to put pressure on the lead firm, or on labour inspectors, to realise employment rights and benefits, including social protection, for homeworkers.

8 In Thailand, HomeNet Thailand is pressuring the government to enforce the legislation though campaigns targeted at factories complying voluntarily, rather than because of inspection, and is loath to litigate.

9 See Trubeck and Trubeck (2006) for ways in which traditional law and new governance approaches complement, or work against each other.

10 See Marshall, Shelley. "New Models of Labour Regulation for Non-Standard and Informal workers", paper presented at the Labour Law Research Network Conference, University of Toronto, June 2017 (on file with author), for examples to illustrate this point.

11 See the United Kingdom's Modern Slavery Act of 2015; and California's Transparency in Supply Chains Act of 2010.

12 See www.ilo.org/dyn/normlex/en/f?p=NORMLEXPUB:13100:0::NO::P13100_ COMMENT_ID:3966155 (accessed 20 June 2019). 